\title{
Élelmiszerek mikotoxin szennyezettségének értékelése
}

\section{Assessment of mycotoxin contamination of foods}

\author{
A. Petranyi ${ }^{1}$, N. Boros ${ }^{2}$, I. BodnaR ${ }^{3}$ \\ 1Debreceni Egyetem, andi.petranyi@gmail.com \\ 2Debreceni Egyetem, nboros@eng.unideb.hu \\ 3Debreceni Egyetem, bodnari@eng.unideb.hu
}

Absztrakt: Az utóbbi években a RASFF rendszer jelentései szerint a legnagyobb problémát a patogén mikroorganizmusok, a peszticid-származékok és a mikotoxinok okozzák. A 2014. évi jelentés adatai alapján elmondha tó, hogy a bejelen tése $12 \%$ - a mi kotoxin eredetü veszélyre hívta fel a figyelmet. Ku tatáso m során a RASFF rendszer miko toxinokra vona tkozó adatait vizsgáltam. Az adato k alapján megállapítható, hogy az összes bejelentés 90\%-a aflatoxinra vonatkozik, melynek csökkenésével az összes bejelentések száma 2004 óta 40\%-kal csökkent. Ezzel szemben az ochratoxin-A jelenléte kismértékben nőtt. Aflatoxint föként diófélékböl és olajos magvakból mutattak ki, legnagyobb mennyiségben földimogyoróból, míg az ochratoxin-A föként gyümölcsökben (több mint 85\%-ban fügében) és füszerekben jelentős. A deoxinivalenol és a fumonizin bejelentések száma lényegesen alacsonyabb ugyan, mint az előző két toxiné, de minden évben jelen voltak a gabonafélékben, többnyire kukoricában és búzában. Zearalenont és patulint a vizsgált időszakban csak 16 és 18 esetben mutattak ki élelmiszerekből, azonban a patulin bejelentések 22\%-a bébiételre vonatkozott, így e toxin vizsgálata is kiemelkedöen fontos.

Abstract: According to RASFF reports, in the present, pathogenic microorganisms, pesticide residues and mycotoxins are the most frequent food contaminants. In 2014, 12\% of the total notifications were caused by mycotoxin contamination. In this study we have analyzed the RASFF notifications that are related to the mycotoxin contaminations. It can be stated that afla toxin is responsible for $90 \%$ of the to tal mycotoxin notifications, and the total notification number has decrease by $40 \%$ since 2004. However the number of oc hratoxin-A notifications are slowly increasing. Aflatoxin was mainly detected in nuts and nut products and oil seeds, especially groundnuts, while ochratoxin-A was detected in fruits (more than 85\% in figs) and spices. The number of deoxynivalenol and fumonisin notifications were significantly less, however some appear every year for cereals and bakery products, especially corn and wheat. Zearalenone and patulin were detected only in 16 and 18 cases but 22\% of the patulin notifications are related to baby food, so the tracking of patulin is really important.

\section{Bevezetés}

Az emberiség számára meghatározó a megfelelő mennyiségű és minőségű, egészséges és biztonságos élelmiszer előállítása. 1992-ben a Nemzetközi Táplálkozási Konferencián a WHO (World Health Organization) kimondta, hogy minden embernek joga van a tápláló és biztonságos élelmiszerekhez. Az 
egyre nagyobb figyelmet kapó élelmiszerbiztonsági tevékenységek mellett mégis gyakran hallunk élelmiszerbotrányokról az Európai Unión belül is.

A szervezetünkre káros anyagok több mint 70\%-a a táplálékkal és ivóvízzel kerül a szervezetünkbe [1]. Egyes források szerint a rosszindulatú daganatos megbetegedések harmada függ össze az elfogyasztott, nem megfelelő élelmiszerrel [2], ezért fontos, hogy megfelelő biztonsági intézkedéseket tegyenek az egyes országok.

Az élelmiszer nyomonkövethetősége további lényeges szempont, mivel enélkül az egyes megbetegedések, szennyezések eredetének visszanyomozása, a kritériumoknak nem megfelelő termékek visszahívása, továbbá a biztonságos globális kereskedelem lebonyolítása lehetetlen lenne. Ennek következményeképpen vagy nem lehetne meghatározni a probléma eredetét, vagy sokkal nagyobb mennyiségben kellene visszahívni a termékeket, mint az szükséges volna [3].

A szervezetünket az élelmiszereken keresztül károsító anyagok lehetnek fizikai, kémiai vagy mikrobiológiai anyagok. A mikrobiológiai anyagok, az élő szervezetek által termelt anyagok, melyek ételfertőzéseket, mérgezéseket, mikotoxikózisokat és egyéb élelmiszerkárosodásokat okozhatnak [4]. A mikotoxinok a penészgombák általában extracellulárisan kiválasztódó, többnyire másodlagos anyagcseretermékei [5]. A gyakorlati szempontból fontosabb raktári penészgombák az Aspergillus- és Penicillium-fajok, melyek számos terméshozamot csökkentő vagy megbetegedést okozó toxint termelnek (aflatoxin, ochratoxin-A, citrinin, patulin, rubratoxin B) [1]. A Fusarium-, Alternaria-, illetve Stachybotrys-fajok a szántóföldi penészek csoportjába tartoznak. A Fusarium-fajok toxinjai közül a zearalenon, a trichotecének, és a fumonizinek jelentenek nagyobb veszélyt [6].

Paterson et al. (2010) szerint az aflatoxin igen gyakori a földimogyoróban, míg a gabonafélék esetén a legnagyobb problémát az ochratoxin-A, a fumonizin, a deoxinivalenol és a zearalenon okozza, de takarmányok esetén jelentős az aflatoxin is. Patulin leggyakrabban almában és abból készült termékekben fordul elő [7].

Munkám célja volt, hogy a fonalas gombák által termelt mikotoxinokat vizsgáljam, a meghatározott hazai és Európai Uniós határértékek, jogszabályok ismerete alapján. Emellett célom volt, hogy az Európai Unióban működő gyorsvészjelző rendszerben (Rapid Alert System for Food and Feed, RASFF) közzétett jelentések tanulmányozásával a mikotoxinok jelentette kockázatot értékeljem, mind hazai mind nemzetközi szinten, és ezek alapján következtetéseket vonjak le a legnagyobb egészségügyi kockázatot jelentő mikotoxinok, illetve kockázatosnak ítélt termékek vizsgálatára vonatkozóan.

\section{Anyag és módszer}

Kutatásom során a RASFF rendszer éves és heti jelentéseit vizsgáltam. E rendszer lehetővé teszi az élelmiszerekkel és takarmányokkal kapcsolatos információk gyors és hatékony áramlását a nemzeti és uniós hatóságok között. Amennyiben a RASFF hálózat valamelyik tagja élelmiszerekből vagy takarmányokból eredő, az emberi egészséget veszélyeztető kockázatról szerez tudomást, ezt az információt a riasztórendszer keretében haladéktalanul jelentenie kell a Bizottságnak. 
Megvizsgáltam, hogy mely országokból érkeztek riasztások, tájékoztatások, illetve milyen esetekben történt határról való visszautasítás. Emellett elemeztem, hogy milyen arányban fordulnak elő az egyes mikotoxinok a bejelentésekben, továbbá, hogy e toxinok mely élelmiszerekben jelennek meg a leggyakrabban. Lehetőségem volt a 2012-2015 közötti részletes heti jelentések elemzésére, melyek között a 2015 évi adatsor értékeit október 12-ig jegyeztem fel, ezek alapján dolgoztam a későbbiekben.

Az összesített adatok alapján értékeltem az egyes országokból származó aflatoxin, ochratoxin-A, fumonizin, deoxinivalenol, zearalenon és patulin által szennyezett élelmiszerekre és takarmányokra érkezett riasztások számát, végül összevetettem ezen adatokat az adott országok által exportált, illetve az Európai Unió által importált mennyiségekkel.

\section{Eredmények értékelése}

A 2006/1881/EC direktíva határozza meg az ajánlott maximális határértékeket az egyes toxinokra vonatkoztatva. Külön határértékeket szabnak meg az emberi fogyasztásra szánt termékek, továbbá a csecsemők számára elérhető termékek kapcsán. A csecsemők számára minden esetben sokkal alacsonyabb határérték a megengedett. Az 1. táblázatban látható, hogy a legszigorúbb határértékek az aflatoxinra és az ochratoxin-A-ra vonatkoznak.

Aflatoxin esetén többek között külön határértéket szab meg az emberi fogyasztás vagy élelmiszerösszetevőként történő felhasználás előtt válogatásnak vagy egyéb fizikai kezelésnek alávetett földimogyoróra ( $8 \mu \mathrm{g} / \mathrm{kg}$ ), diófélékre ( $5 \mu \mathrm{g} / \mathrm{kg}$ ), szárított gyümölcsökre ( $5 \mu \mathrm{g} / \mathrm{kg}$ ), kukoricára ( 5 $\mu \mathrm{g} / \mathrm{kg}$ ), illetve valamennyi gabonafélére vagy az azokból készült termékekre ( $2 \mu \mathrm{g} / \mathrm{kg}$ ). Közvetlen fogyasztás esetén nem haladhatják meg a $2 \mu \mathrm{g} / \mathrm{kg}$ értéket. Bizonyos füszerfajtákra $5 \mu \mathrm{g} / \mathrm{kg}$ értéket szab meg. Anyatej-helyettesítő és anyatej-kiegészítő tápszerek esetén, továbbá csecsemőknek szánt speciális gyógyászati célú diétás termékekben pedig $0,025 \mu \mathrm{g} / \mathrm{kg}$ értéket nem haladhatja meg a mennyisége.

\begin{tabular}{|c|l|l|}
\hline & \multicolumn{2}{|c|}{ Határérték $(\mu \mathrm{g} / \mathrm{kg})$} \\
\hline & Emberi fogyasztásra szánt termék & Csecsemőknek szánt termék \\
\hline Aflatoxin & $2-8$ & $0,025-0,1$ \\
\hline Aflatoxin M1 (nyers tej) & 0,05 & $0,025-0,1$ \\
\hline Ochratoxin-A & $2-10$ & 0,5 \\
\hline Deoxinivalenol & $500-1750$ & 200 \\
\hline Zearalenon & $50-200$ & 20 \\
\hline Fumonizin B1+B2 & $400-2000$ & 200 \\
\hline Patulin & $25-50$ & 10 \\
\hline
\end{tabular}


International Journal of Engineering and Management Sciences (IJEMS) Vol. 1. (2016). No.2.

DOI: 10.21791/IJEMS.2016.2.12.

1. táblázat: Emberi fogyasztásra szánt élelmiszerek mikotoxin tartalmára vonatkozó határértékek (forrás:

2006/1881/EC)

Az ochratoxin-A mennyisége legfeljebb $2 \mu \mathrm{g} / \mathrm{kg}$ lehet közvetlen emberi fogyasztásra szánt szőlőlében, mustban, borban, illetve minden szőlő és bor alapú italban. Feldolgozatlan gabonafélékben ez az érték $5 \mu \mathrm{g} / \mathrm{kg}$, közvetlen fogyasztás esetén $3 \mu \mathrm{g} / \mathrm{kg}$. Az instant kávé kivételével, minden típusú kávéban 5 $\mu \mathrm{g} / \mathrm{kg}$ a határérték, oldható kávé esetén $10 \mu \mathrm{g} / \mathrm{kg}$. Szintén $10 \mu \mathrm{g} / \mathrm{kg}$ a szárított szőlőben található ochratoxin-A megengedett maximális értéke.

A közvetlen emberi fogyasztásra szánt kukoricaételekben, kenyérben a fumonizin mennyisége 400 $\mu \mathrm{g} / \mathrm{kg}$, míg a deoxinivalenol mennyisége $500 \mu \mathrm{g} / \mathrm{kg}$ lehet, viszont feldolgozatlan kukoricában a fumonizin elérheti a $2000 \mu \mathrm{g} / \mathrm{kg}$-ot, míg a deoxinivalenol az $1750 \mu \mathrm{g} / \mathrm{kg}$ értéket. Közvetlen fogyasztásra szánt gabonafélék, illetve száraz tészta esetén $750 \mu \mathrm{g} / \mathrm{kg}$ a deoxinivalenol-határérték.

A zearalenon szintén a kenyérben, illetve a kukoricapelyhekben lehet a legkevesebb ( $50 \mu \mathrm{g} / \mathrm{kg}$ ), míg a feldolgozatlan és a közvetlen fogyasztásra szánt termékekben elérheti a $200 \mu \mathrm{g} / \mathrm{kg}$-ot is. A patulin mennyisége szilárd almaételekben $25 \mu \mathrm{g} / \mathrm{kg}$, míg a gyümölcslevekben és szeszes italokban $50 \mu \mathrm{g} / \mathrm{kg}$ lehet.

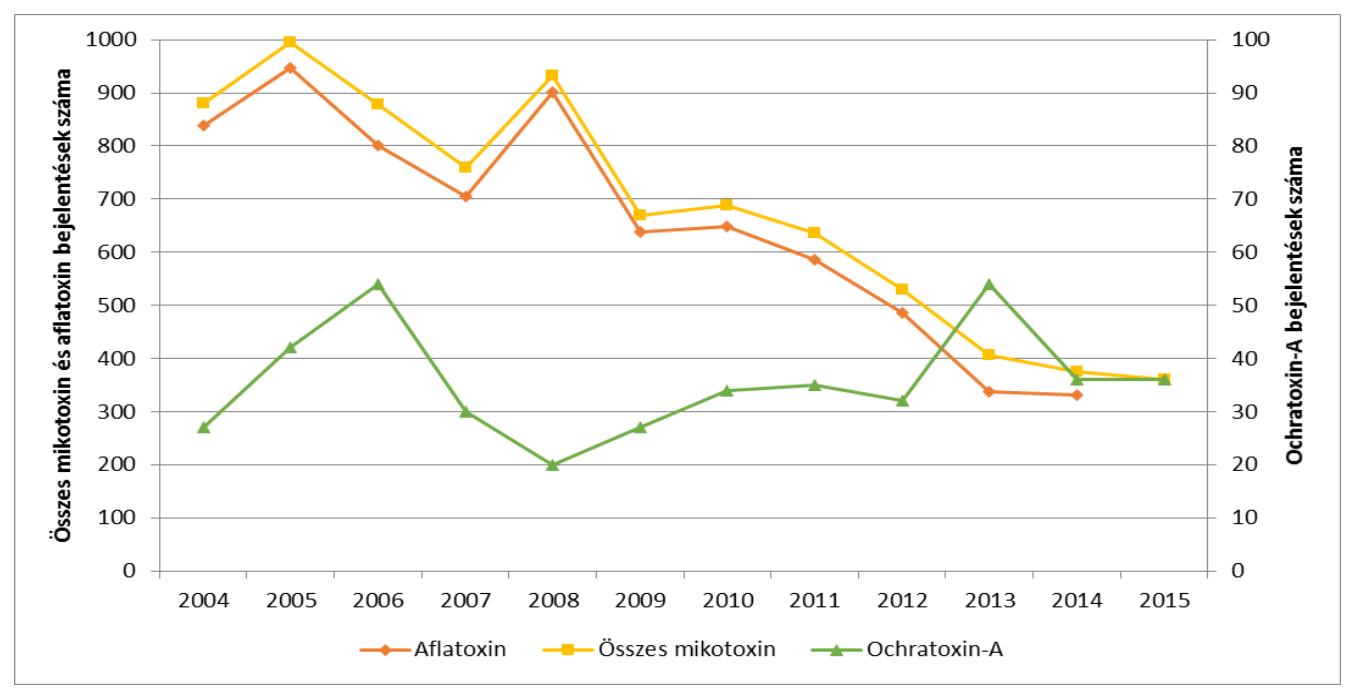

1. ábra: Az összes mikotoxin, aflatoxin és ochratoxin-A bejelentések számának változása 2004-2015 között

Az 1. ábrán a 2004-2015 közötti összes mikotoxin, aflatoxin és ochratoxin-A bejelentések számának változása látható.

Ezen időszak alatt két évben volt kiemelkedően sok bejelentés, 2005-ben, illetve 2008-ban, e két év kivételével csökkenés figyelhető meg. 2009-ben, az előző év nagyszámú bejelentéseinek hatására az Európai Unió szigorított az importra vonatkozó szabályokon, továbbá növelte az ellenőrzések gyakoriságát az unión kívül eső országokból történő behozatal kapcsán. A korábbi évek adatai alapján 
ez a Kínából és Törökországból származó földimogyoróra, illetve a Törökországból érkező pisztáciára és fügére vonatkozott elsődlegesen. Megfigyelhető, hogy 2008 után jelentősen lecsökkent a bejelentések száma, mely valószínűleg e szigorításoknak tudható be. Az összes bejelentések számát az aflatoxin jelenléte határozza meg, így a két görbe alakja közel azonos.

Ochratoxin-A-t igen változó mennyiségben regisztráltak a vizsgált időszakban, melynek mennyisége nincs összefüggésben az adott év aflatoxin bejelentés eivel. 2005-ben, 2006-ban és 2013-ban a korábbi évekhez képest megnövekedett a bejelentések száma. 2005-ben és 2006-ban is a bejelentések közel fele mazsolából kimutatott ochratoxin-A-ra hívta fel a figyelmet, melyet 2005-ben Törökországból és Iránból, míg 2006-ban Üzbegisztánból importáltak. Ennek okán 2007-től szigorítottak e termék nyomon követésén, így 2007-től nagymértékben csökkentek a bejelentések. 2013-ban, Törökországból importált füge kapcsán nőtt meg jelentősen a bejelentések száma, az előző évi 32 bejelentéshez képest, 54 bejelentést regisztráltak.

A 2. ábrán az egyéb élelmiszerek szempontjából jelentős mikotoxinok mennyiségének változása látható 2004-2015 között. Ebben az időszakban minden évben érkezett bejelentés fumonizinre vonatkozóan, illetve 2007-től deoxinivalenolra is. Deoxinivalenol minden évben Európából származó termékben volt jelen, két Kínából érkező terméket leszámítva. Magyarországról származó búzában, kukoricában, illetve azokból készült termékekben 2007-ben 2, 2008-ban 1, 2009-ben 1, 2011-ben 3 és 2015-ben szintén 1 alkalommal érkezett bejelentés. Ez alapján Lengyelország az első, míg Magyarország a második leggyakrabban jelentett ország deoxinivalenol szempontjából.

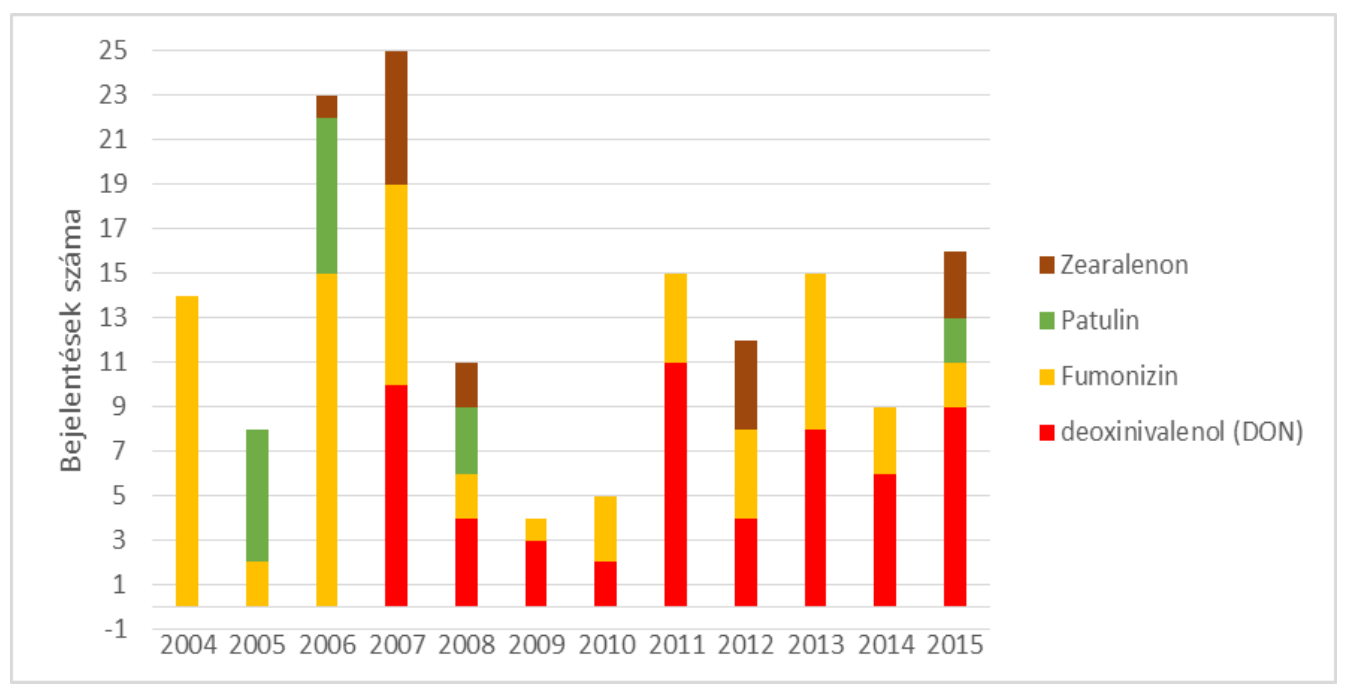

2. ábra: Egyéb jelentős mikotoxinok bejelentések száma 2004 és 2015 között

A fumonizin bejelentések száma 2004-ben és 2006-ban volt a legmagasabb. A legtöbb bejelentés (37/66, 56\%) olasz eredetű gabonaféléről érkezett, melynek jelentős része (31) 2004 és 2009 között volt. Az utóbbi 5 évben a 23 esetből már csak 6 Olaszországból származó terméket jelentettek be, melyek mellett Argentínából 4, Peruból 3, Egyesült Királyságból 2 és Magyarországról szintén 2 (2014, 2015) terméket utasítottak vissza. 
Patulint 2004 óta összesen 4 évben jelentettek, főként almában vagy almakészítményekben található meg. Viszont 4 alkalommal bébiételekből mutatták ki, ami felhívja a figyelmet arra, hogy e toxint fontos vizsgálni. Az idei évben már 2 bejelentés érkezett, Belgiumból származó almalében mutattak ki határérték felett patulin szennyezést. 2008-ban Magyarországról származó almapürében is kimutatták.

Zearalenon miatt szintén ritkán érkezik bejelentés, eddig 2006-ban, 2007-ben, 2008-ban, 2012-ben és 2015-ben, összesen 17 jelentést regisztráltak. A 17 bejelentésből 15 Európából származó gabonára vagy abból készült termékre vonatkozott.

\section{Következtetések}

Az elmúlt 10 év adatai alapján egyértelműen megállapítható, hogy a legnagyobb problémát az aflatoxin termelő gombák jelenléte okozza, mind a mezőgazdaságban, mind az élelmiszeriparban. E toxin az általa okozott egészségügyi problémák (rákkeltő hatás) miatt különös figyelmet igényel. Az aflatoxin legnagyobb mennyiségben diófélékben és olajos magvakban fordul elő, mint például földimogyoróban, mogyoróban, pisztáciában és mandulában. Aflatoxin M1-et 2004 óta 9 alkalommal mutattak ki tejből, a 9 bejelentésből 6 Magyarországról származó tejet jelentett 2007-ben, 2012-ben és 2013-ban.

2010 óta jelentősen csökkent a bejelentések száma, ami valószínűleg az Európai Unió szigorodó szabályainak, illetve a nyomonkövethetőség kiépítésének köszönhető.

A második legnagyobb problémát az ochratoxin-A okozza. E toxin esetén kismértékü növekedés figyelhető meg a vizsgált 10 év átlagában. Fontos megjegyezni, hogy az ochratoxin-A bejelentések száma független az aflatoxin bejelentések számának változásától. Mivel hőmérsékleti optimumuk nem esik egybe, ezért a melegebb nyarakon valószínúleg inkább az aflatoxin a domináns, míg azon nyarakon, mikor a hőmérséklet $30^{\circ} \mathrm{C}$ fölé nem, vagy csak ritkán emelkedik nagyobb a valószínűsége az ochratoxin-A termelődésének. E toxin főként gyümölcsökből mutatható ki, azon belül is legnagyobb mennyiségben aszalt vagy szárított fügéből és mazsolából.

Az aflatoxinnal vagy ochratoxin-A-val szennyezett füge közel 100\%-ban Törökországból származik.

A deoxinivalenol leggyakrabban Lengyelországból és Magyarországról érkező termékekben, fóként kukoricában és búzában volt jelen, a beérkezett jelentések 32\%-a e két országból származó terméket érintett.

Patulint ugyan a 10 év alatt mindössze 18 alkalommal jelentettek, viszont fontosnak tartom a folyamatos ellenőrzését, hiszen főként almából és körtéből kimutatható toxin, mely gyakori alapanyaga a bébiételeknek. A 18 bejelentésből 4 bébiételből kimutatott patulinra vonatkozott. A csecsemőket fokozottan védeni kell a toxinoktól, hiszen már sokkal kisebb dózisban is kifejthetik káros hatásukat. 
International Journal of Engineering and Management Sciences (IJEMS) Vol. 1. (2016). No.2.

DOI: 10.21791/IJEMS.2016.2.12.

\section{Hivatkozások}

[1] M. Kovács, Aktualitásoka mikotoxin kutatásban, Kaposvár, 2010, ISBN 978-963-502-912-9.

[2] P. Laczay, Rákkeltố vegyi anyagok az élelmiszerláncban, Magyar Állatorvosok Lapja, 2012, vol.134, 491-503.

[3] M. Szeitzné Szabó, K. Frecskáné Csáki, Az aflatoxin szennyezettség csökkentésének lehetôségei az élelmiszerláncban, Nemzeti Élelmiszerlánc-biztonsági hivatal, 2013.

[4] G. Bíró, Gy. Bíró, Élelmiszer-biztonság. Táplálkozás-egészségügy, Agroinform Kiadó, Nyomda Kft., 2000, ISBN 963-502-25-7.

[5] Sz. Kovács, T. Pusztahelyi, M. Borbélyné Varga, Az aflatoxin képződése mezőgazdasági termékeken, Agrártudományi Közlemények, 2014, vol. 56, 67-71.

[6] J.D. Miller, Mycotoxins in small grains and maize: Old problems, new challenges, Food Additives and Contaminants, 2008, vol.25, 219-230.

[7] R.R.M. Paterson, N. Lima, How will climate change affect mycotoxins in food? Food Research International, 2010, vol.43, 1902-1914. 